\title{
Are Non-Native Gastropods a Threat to Endangered Lichens?
}

\author{
ROBERT CAMERON
}

\begin{abstract}
Nova Scotia Environment, Protected Areas Branch, P.O. Box 442, Halifax, Nova Scotia B3J 2P8 Canada; e-mail: camerorp@ gov.ns.ca
\end{abstract}

Cameron, Robert. 2009. Are non-native gastropods a threat to endangered lichens? Canadian Field-Naturalist 123(2): 169-171.

Extensive grazing by gastropods was found on endangered Boreal Felt Lichen (Erioderma pedicellatum) at Sixth Lake, Nova Scotia, in 2004. At least $80 \%$ of arboreal gastropods observed at the site were the introduced species Arion subfuscus. Subsequent surveys at five other locations in Nova Scotia showed $90 \%$ of arboreal gastropod individuals observed were introduced species. Potential impact on native lichen species, and in particular on rare and endangered species, is discussed.

Key Words: Boreal Felt Lichen, Erioderma pedicellatum, gastropods, non-native, Nova Scotia.

Erioderma pedicellatum (Boreal Felt Lichen) is an epiphytic foliose lichen found in the temperate and boreal northern hemisphere. The world population of E. pedicellatum has been listed as critically endangered by the International Union for the Conservation of Nature. In Canada, the Atlantic population, occurring in Nova Scotia and New Brunswick, has been listed as endangered under the Canadian Species at Risk Act and provincially under the Nova Scotia Endangered Species Act. In Nova Scotia, the population declined by $90 \%$ between the early 1980 s and the 1990s (Maass and Yetman 2002*). Researchers have visited the known $E$. pedicellatum localities annually since 2004 to evaluate health and condition. There are 180 thalli in 30 locations known for Nova Scotia (Cameron et al. 2010).

During a re-visit to the Sixth Lake site $\left(44^{\circ} 54^{\prime} \mathrm{N}\right.$, $62^{\circ} 43^{\prime} \mathrm{W}$ ) in fall 2004, I found evidence of extensive grazing on the single Erioderma pedicellatum thallus at the site. Sixth Lake occurs on the eastern edge of the Tangier Grand Lake Protected Wilderness Area, Halifax County. About $60 \%$ of this thallus had been grazed and it appeared that about $80 \%$ of trees at the site harboured slugs on the trunks. Arion subfuscus, a non-native introduction from Europe, was the dominant arboreal slug found at the site at the time, making up about $80 \%$ of individuals found on trees. A voucher specimen was collected and will be deposited in the Nova Scotia Museum of Natural History. The only other species found was a native species, Pallifera dorsalis. Other lichen species with evidence of grazing included Coccocarpia palmicola, Hypogymnia physodes and Parmelia squarrosa. Coccocarpia palmicola is relatively uncommon in Nova Scotia (Cameron and Neily 2008), while Hypogymnia physodes and Parmelia squarrosa are very common (Casselman and Hill 1995; Cameron 2004; McMullin et al. 2008).

To help determine the magnitude of the potential threat to rare lichens from this introduced gastropod, subsequent surveys were conducted. Five mixed-wood forest sites in central Nova Scotia were surveyed for arboreal gastropods between 10 October 2005 and 3 September 2006. Locations of survey sites are Tangier Grand Lake Wilderness Area $\left(44^{\circ} 53^{\prime} \mathrm{N}, 62^{\circ} 50^{\prime} \mathrm{W}\right)$,

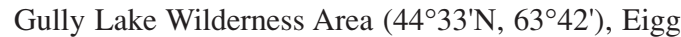
Mountain-James River Wilderness Area $\left(45^{\circ} 41^{\prime} \mathrm{N}\right.$, $\left.62^{\circ} 10^{\prime} \mathrm{W}\right)$ and MacPhees Corner Hants County $\left(45^{\circ} 07^{\prime} \mathrm{N}, 63^{\circ} 32^{\prime} \mathrm{W}\right)(2$ sites). Site descriptions and location details can be found in Cameron et al. (2007) and Cameron and Richardson (2006). Sites were visited during days when gastropod activity was likely to be the highest, with daytime temperatures of greater than $10^{\circ} \mathrm{C}$ and an overcast sky with fog, drizzle or rain. One hundred trees (20 per site) of either Acer rubrum (Red Maple) or Abies balsamea (Balsam Fir) were examined for the presence of gastropods between the ground and $2 \mathrm{~m}$ up the trunk. Trees were selected for study by walking into the centre of the stand and choosing the closest trees of suitable species. Gastropod species (slugs and snails) were identified and, if they were actively feeding, the lichen species being grazed was also recorded. Identification of species was done using Burch (1962) and Burch and Jung (1988). There are several cryptic species of the Arion fuscus/subfuscus complex (Barr et al. 2009). However, since no collections of Arion fuscus in Nova Scotia had been reported in the literature up to Davis (1992), all species keyed to Arion fuscus or A. subfuscus were considered $A$. subfuscus for this study.

Twenty-one gastropods representing three slug species were found. No snails were found. Over $76 \%$ (16 of 21) of gastropods found were non-native Arion subfuscus. Four individuals (19\%) were Deroceras reticulatum, also a non-native slug. Only one native gastropod species (Pallifera dorsalis) was found, and it was on Acer rubrum. Arion subfuscus was found more commonly on Acer rubrum ( $80 \%$ of findings) than on Abies balsamea. Deroceras reticulatum was found only on Acer rubrum. Species of lichens grazed included Lobaria pulmonaria, Parmelia squarrosa, Parmelia sulcata and Platismatia glauca. Lobaria pulmonaria is widespread and common in Nova Scotia (Anderson 2007), as are Parmelia squarrosa and Platismatia glauca (Casselman and Hill 1995; Cameron 2004; McMullin et al. 2008 ).

It is notable that $90 \%$ of arboreal gastropod individuals found were introduced species. Some caution is needed with this number because many native spe- 
cies, which are much smaller than introduced species (Davis 1992), are more difficult to detect. Also, some species forage only at night or at very low light levels (Gauslaa et al. 2006). Nevertheless, under the investigated conditions, there appears to be a very high proportion of non-native arboreal gastropod foragers. Little is known about the distribution and abundance of terrestrial gastropods in Nova Scotia. However, Davis (1992) suggests that Arion subfuscus is common and widespread, having naturalized to mixed and deciduous forests. Davis and Browne (1996) suggest that non-native species, like Arion subfuscus, have restricted Pallifera dorsalis to native forests.

It is uncertain whether the non-native species are outcompeting the native species or are filling a previously unfilled niche. The former seems more likely, since native arboreal foragers are present. Non-native gastropods can compete for resources or can prey on native species. Non-native terrestrial gastropod introductions have resulted in the decline of native species diversity and even the extinction of native species in other areas (Hadfield 1986; Proschwitz 1994; Mahtfeld 2000).

The impact of non-native gastropod grazers on native lichens is uncertain. Other studies suggest that lichens can recover from grazing by gastropods (Fröberg et al. 2006; Gauslaa et al. 2006). Asplund and Gauslaa (2008) indicate that grazing by molluscs may limit growth and early development of Lobaria pulmonar$i a$ in calcareous deciduous forest. However, previous studies have documented only the impacts of grazing by native gastropods. To my knowledge, this is the first documentation of non-native gastropod grazing on lichens.

No grazing animal was found on the Erioderma pedicallatum thallus at Sixth Lake. However, the pattern of grazing was indicative of gastropods (Sharnoff and Rosentreter 1998*). The typical gastropod feeding tracks were quite wide, indicating a larger species like Arion subfuscus.

The disappearance of two thalli at another site, Jacket Lake $\left(44^{\circ} 45^{\prime} \mathrm{N}, 62^{\circ} 42^{\prime} \mathrm{W}\right)$, may also have been caused by grazing. The Jacket Lake site is less than $2 \mathrm{~km}$ from the Sixth Lake site. The Jacket Lake site was visited in August 2006, when it was noted that two Erioderma pedicellatum thalli were healthy with minimal evidence of grazing. Researchers failed to locate two mature thalli on the same tree at the Jacket Lake site when it was revisited in March 2007. Careful examination of the locations on the tree where the thalli had been revealed small fragments of thalli that showed evidence of grazing. It could not be determined whether grazing was entirely responsible for the loss of these two thalli. It is, however, significant to note the rapid loss in less than 7 months of these two healthy thalli.

Cameron et al. (2009*) found evidence of grazing on Erioderma mollissimum, another rare cyanolichen found in Nova Scotia. Of 96 thalli observed between 2006 and 2008, 12 (13\%) showed evidence of grazing. The area of the thalli grazed ranged from 1 to $20 \%$. Most grazing had patterns typical of small invertebrates such as orbatid mites or Collembola. Only 3 thalli had grazing patterns typical of gastropods.

Further research is needed to determine the impact these non-native gastropod species may be having on native lichens and on rare and endangered lichens in particular.

\section{Acknowledgments}

Funding was provided in part by the Habitat Stewardship Program, Environment Canada and Nova Scotia Environment. Thanks to Julie Towers and two anonymous reviewers for manuscript reviews.

\section{Documents Cited (marked * in text)}

Cameron, R. P., T. Neily, S. R. Clayden, and W. S. G. Maass. 2009. COSEWIC Draft Status Report on Vole Ears Erioderma mollissimum. Committee on the Status of Endangered Wildlife in Canada, Ottawa. 64 pages.

Maass, W. S. G., and D. Yetman. 2002. COSEWIC Assessment and Status Report on the Boreal Felt Lichen (Erioderma pedicellatum) in Canada. Committee on the Status of Endangered Wildlife in Canada, Ottawa. 50 pages.

Sharnoff, S., and R. Rosentreter. 1998. Lichen use by wildlife in North America. Website http://www.lichen. com/fauna.html accessed 23 December 2008.

\section{Literature Cited}

Anderson, F. 2007. An assessment of the status of cyanolichens in Nova Scotia. Evansia 24: 23-24.

Asplund, J., and Y. Gauslaa. 2008. Mollusc grazing limits growth and early development of the old forest lichen Lobaria pulmonaria in broadleaf deciduous forests. Oecologia 155: 93-99.

Barr, N. B., A. Cook, P. Elder, J. Molongoki, D. Prasher, and D. G. Robinson. 2009. Application of a DNA barcode using the 16S rRNA gene to diagnose pest Arion species in the USA. Journal of Molluscan Studies 75: 187-191.

Burch, J. B. 1962. How to Know the Eastern Land Snails. Wm. C. Brown Company, Dubuque. 214 pages.

Burch, J. B., and Y. Jung. 1988. Land snails of the University of Michigan Biological Station area. Walkerana 3: 1-177.

Cameron, R. P., and T. Neily. 2008. Heuristic model for predicting habitat of Erioderma pedicellatum and other rare cyanolichens in Nova Scotia, Canada. The Bryologist 111: 650-658.

Cameron, R. P., and D. H. S. Richardson. 2006. Occurrence and abundance of epiphytic cyanolichens in protected areas in Nova Scotia. Opuscula Philolichenum 3: 5-14.

Cameron, R. P., T. Neily, and D. H. S. Richardson. 2007. Macro-lichen indicators of air quality in Nova Scotia. Northeastern Naturalist 14: 1-14.

Cameron, R. P., C. Hanel, I. Godie, and T. Neily. 2010. Erioderma pedicellatum, boreal felt lichen: current status, conservation issues and future prospects. Botanical Electronic News 420: available at http://www.ou.edu/cas/ botany-micro/ben/ben420.html\#4.

Casselman K. L., and J. M. Hill. 1995. Lichens as a monitoring tool: a Pictou County (Nova Scotia) perspective. 
Pages 237-244 in Ecosystem Monitoring and Protected Areas. Proceedings of the Second International Conference on Science and the Management of Protected Areas, Dalhousie University, Halifax, Nova Scotia, Canada, 16-20 May 1994. Edited by T. B. Herman, S. Bondrup-Nielsen, J. H. M. Willison, and N. W. P. Munro. Science and the Management of Protected Areas Association, Wolfville.

Davis, D. S. 1992. Terrestrial Mollusca of Nova Scotia: in the footsteps of John Robert Willis, 1825-1876. Proceedings of the Ninth International Malacological Congress 9: 125133.

Davis, D., and S. Browne. 1996. Natural History of Nova Scotia. 2 volumes. Nimbus Publishing, Halifax. 500 pages.

Fröberg, L., A. Baur, and B. Baur. 2006. Differential herbivore damage to calcicolous lichens by snails. Lichenologist 38: 491-493.

Gauslaa, Y., H. Holien, M. Ohlson, and T. Solhøy. 2006. Does snail grazing affect growth of the old forest lichen Lobaria pulmonaria? Lichenologist 38: 587-593.
Hadfield, M. G. 1986. Extinction in Hawaiian achatinelline snails. Malacologia 27: 67-81.

Mahtfeld, K. 2000. Impact of introduced gastropods on molluscan communities, northern North Island. Conservation Advisory Science Notes No. 277, Department of Conservation, Wellington. 18 pages.

McMullin, R. T., P. N. Duinker, R. P. Cameron, D. H. S. Richardson, and I. M. Brodo. 2008. Lichens of coniferous old-growth forests of southwestern Nova Scotia, Canada: diversity and present status. The Bryologist 111: 620-637.

Proschwitz, T. von. 1994. Oxychilus cellarius (Muller) and Oxychilus draparnaudi (Beck) as predators on egg-clutches of Arion lusitanicus Mabille. Journal of Conchology 3: 183-184.

Received 27 January 2009

Accepted 7 March 2010 